\title{
Genetic Kinship and Sex Determination of Early Modern Period Human Remains from a Defunct Graveyard in the Former Village of Obora (Located on Šporkova Street in Prague's Lesser Town District)
}

\author{
Jana Nováčkováa ${ }^{*}$, Otakara Řebounováb, Dana Kvítkovác, Martin Omelka ${ }^{\mathrm{b}}$, Vlastimil Stenzl ${ }^{\mathrm{c}}$ \\ anstitute of Archaeology CAS, Letenská 4, Prague, Czech Republic \\ ${ }^{b}$ Prague City Archives, Archivni 6, Prague, Czech Republic \\ 'Institute of Criminalistics, Bartolomějská 310/12, Prague, Czech Republic
}

\section{ARTICLE INFO}

\section{Article history:}

Received: $1^{\text {st }}$ May 2019

Accepted: $15^{\text {th }}$ October 2019

DOI: http://dx.doi.org/ 10.24916/iansa.2019.2.4

\section{Key words}

Early Modern Period

ancient DNA (aDNA)

genetic analyses

short tandem repeats

Y-chromosome

autosome

\begin{abstract}
$A B S T R A C T$
The main aim of this study was to determine genetic kinship and genetic sex of individuals buried either in the same grave, multi-level grave, or neighbourhood grave. Success of genetic analyses is based on the quantity and quality of extracted aDNA, which can be compromised by degradation of DNA and possible contamination by modern DNA. We analysed archaeological skeletal remains from an Early Modern period graveyard belonging to the Church of St. John the Baptist in the former village of Obora, one of the most honourable Early Modern period archaeological sites in the Czech Republic. Most of the 906 excavated anatomically-laid burials are dated to the years $1730 \mathrm{~s}-1770 \mathrm{~s}$. The results of 23 analysed individuals (divided into 4 groups) revealed that individuals are not blood relatives. Studies of historical written sources provide information that the parish affiliation at the time of death had a crucial role in choosing the place for burial. Genetic analyses increased success rate of sex determination to $91 \%$ compared to $61 \%$ determined by morphological methods. We were thus able to determine the genetic sex of children, an evaluation that cannot be made by morphological methods.
\end{abstract}

\section{Introduction}

The implementation of genetic analyses into studies of archaeological skeletal remains can provide information about genetic kinship (Ciu et al., 2015; Deguilloux et al., 2014) and the genetic sex of children, when incomplete and poorly-preserved skeletons (Álvarez-Sandova et al., 2014; Lassen et al., 2000; Tierney, Bird, 2014) cannot be reliably determined with different methods. Analyses of ancient DNA (aDNA) have been previously used in demographic studies of skeletal archaeological remains from several archaeological sites in the Czech Republic, for example, by Boberová et al., 2012, Bravermanová et al., 2018, or Frolík et al., 2017. The determination of genetic kinship among the buried individuals would give an important insight into understanding funerary practices, and the social and demographic structures of historical cultures.

*Corresponding author. E-mail: novackova.janka@gmail.com
Additional useful information can also be obtained from written historical sources, such as civil and parish registers, testaments and chronicles.

The quality of genetic analyses of aDNA are negatively influenced by two major problems: its degradation into small fragments; and the contamination of aDNA with modern DNA. Firstly, over time, the DNA will become damaged and broken into small fragments due to its inhospitable environmental conditions (Hofreiter et al., 2001,pp. 353-354; Pääbo et al., 2004, pp.654-660). Secondly, contaminant DNA can come from individuals who were in contact with the skeletal remains (archaeologists, anthropologists, or geneticists in the laboratory), as well as from chemical reagents, laboratory, or cross-sample contaminations. While working with our samples for genetic analyses, we followed the instructions published by Yang and Watt (2005).

Archaeogenetic research of genetic kinship is based on analyses of uniparental markers (Y-chromosome and mitochondrial DNA) and autosomal STR markers 


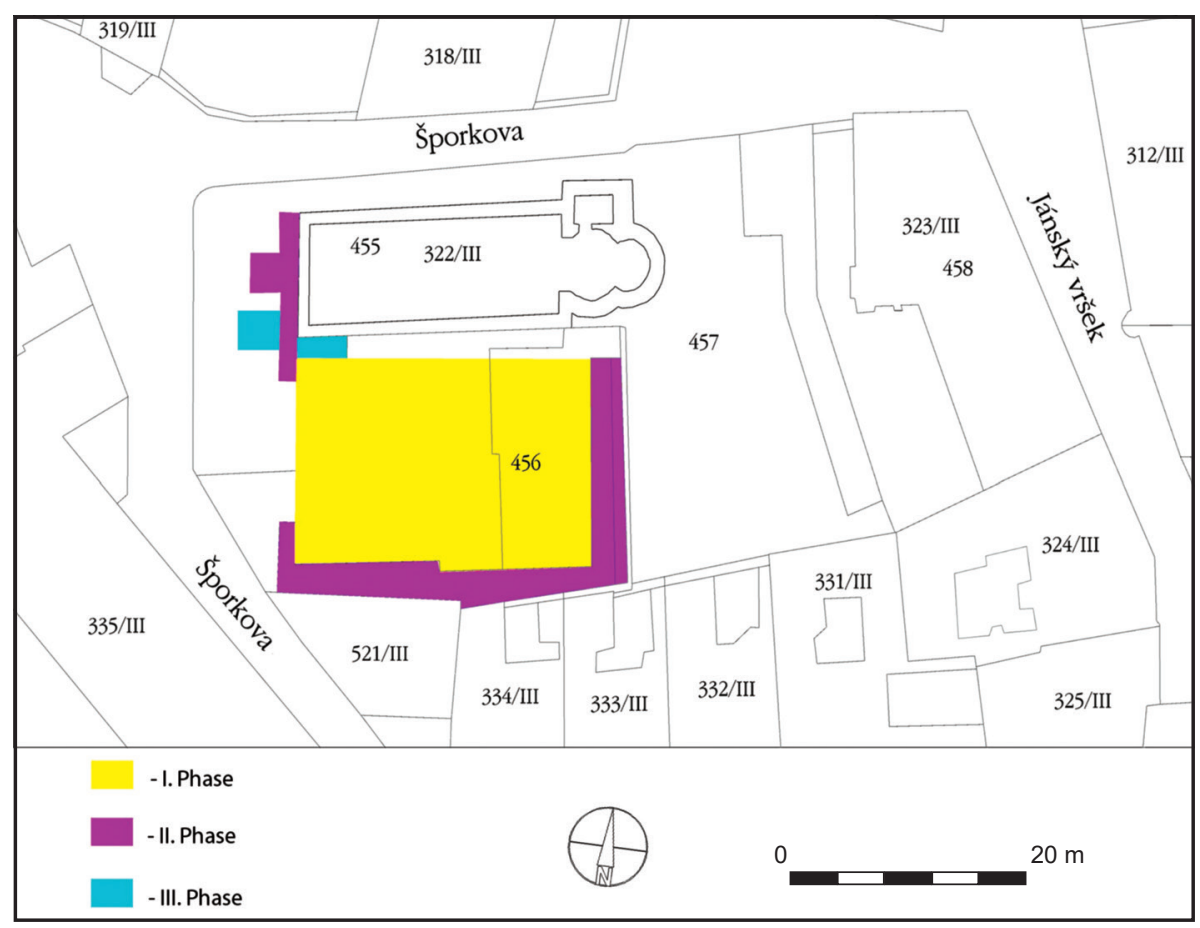

Figure 1. The plan of three phases of excavations at the defunct graveyard of the Church of St. John the Baptist and ground plan of the church. The archaeological rescue excavation was carried out only on the part of graveyard in which construction work took place on (Omelka, 2006b, unpublished). Drawn by Martin Omelka.

(Deguilloux et al., 2014; Juras et al., 2017; Melchior et al., 2010; Simón et al., 2011). Each marker has its own unique mechanism of heritability from parent to offspring, and can reveal or exclude genetic relationships at different levels. We analysed the skeletal remains from a defunct graveyard of the Church of St. John the Baptist in the former village of Obora, situated at Šporkova Street no. 322/III in Prague, the capital of the Czech Republic. Genetic kinship and genetic sex was determined from the results of autosomal and Y-chromosomal STR markers.

The site of Obora used to be a village located near Prague castle in the quarter known as Prague's Lesser Town. The first written record referencing Obora is dated to the years 12781282, but previous excavation has uncovered fragments dated to between the $9^{\text {th }}-10^{\text {th }}$ century (Dragoun, 1988a; 1988 b; 1991). Obora was assigned to Prague in the 1650s, and its Church of St. John the Baptist was incorporated into the parish district of the Church of St. Wenceslas. The church with its graveyard was closed in 1784, and rebuilt into a residential building (Omelka, 2009). Skeletal remains of 906 anatomically-laid burials or parts thereof, that were dated to the years $1730 \mathrm{~s}-1770 \mathrm{~s}$ according to their grave goods, were excavated and documented during the archaeological rescue excavation conducted by the Department of Archaeology of the National Heritage Institute in Prague in the year 2002 (study no. 30/02) and 2004 (study no. 30/04) - Figure 1. The archaeological location in Šporkova Street is one of the most valuable Early Modern period archaeological sites in the Czech Republic due to the assemblage collection of grave goods and preserved written historical sources, providing great possibilities to study: funerary customs among the burgher citizens of the time (Omelka, Řebounová, 2017); other manifestations of Baroque religiousness (Omelka,
Řebounová, 2011; 2014); as well as social and demographic structures among this population (Omelka, Řebounová, 2012b). Several articles were published (mainly in Czech peer-reviewed journals) regarding artefacts found in the grave, including goods such as rings (Omelka, Šlancarová, 2007), beads (Omelka, Řebounová, 2008), crosses (Omelka et al., 2009; 2010), pins (Omelka et al., 2011), a medallion (Omelka, 2006a; Omelka, Řebounová, 2012a; 2016) and buttons (Omelka et al., 2018). Pilot results of genetic analyses of 11 individuals were presented at the International conference "Internationale Tagung der Österreichischen Gesellschaft für Mittelalterarchäologie 2018" in Sankt Pölten (Austria) (Nováčková et al., in press). In the present study, we increased the number of analysed individuals to confirm or reject the hypothesis that the pattern of funerary practices of Early Modern society, as suggested by the pilot study, would hold up under further examination.

\section{Material and methods}

We analysed a total of 46 samples (bones and teeth) from 23 individuals (Table 1), of which 12 individuals (group 3 and group 4) are newly published, and 11 individuals (group 1 and group 2) were previously published (Nováčková et al., in press). Individuals were divided into four groups (Table 1) according to their stratigraphic relationships in the graveyard (Figure 2). The groups contain the genetic material of men, women and children, except for group 2, where two children (newborn and 18 months old) were buried just above an adult woman. Multi-level graves contained skeletal remains of adult women, men and children and so there is a high probability that they are members of one family (for example, 
Figure 2. Flowcharts by Jiří Vachuda. The flowcharts are parts of unpublished documentation of research in Šporkova Street, schematically representing the position of graves on the burial site in the geometrically defined sectors. Each sector is designated by a different colour. Some skeletons intersected more than one sector, and so are labelled using more than one colour. The results of the computer analysis of genetic kinship are the nearby flowcharts.
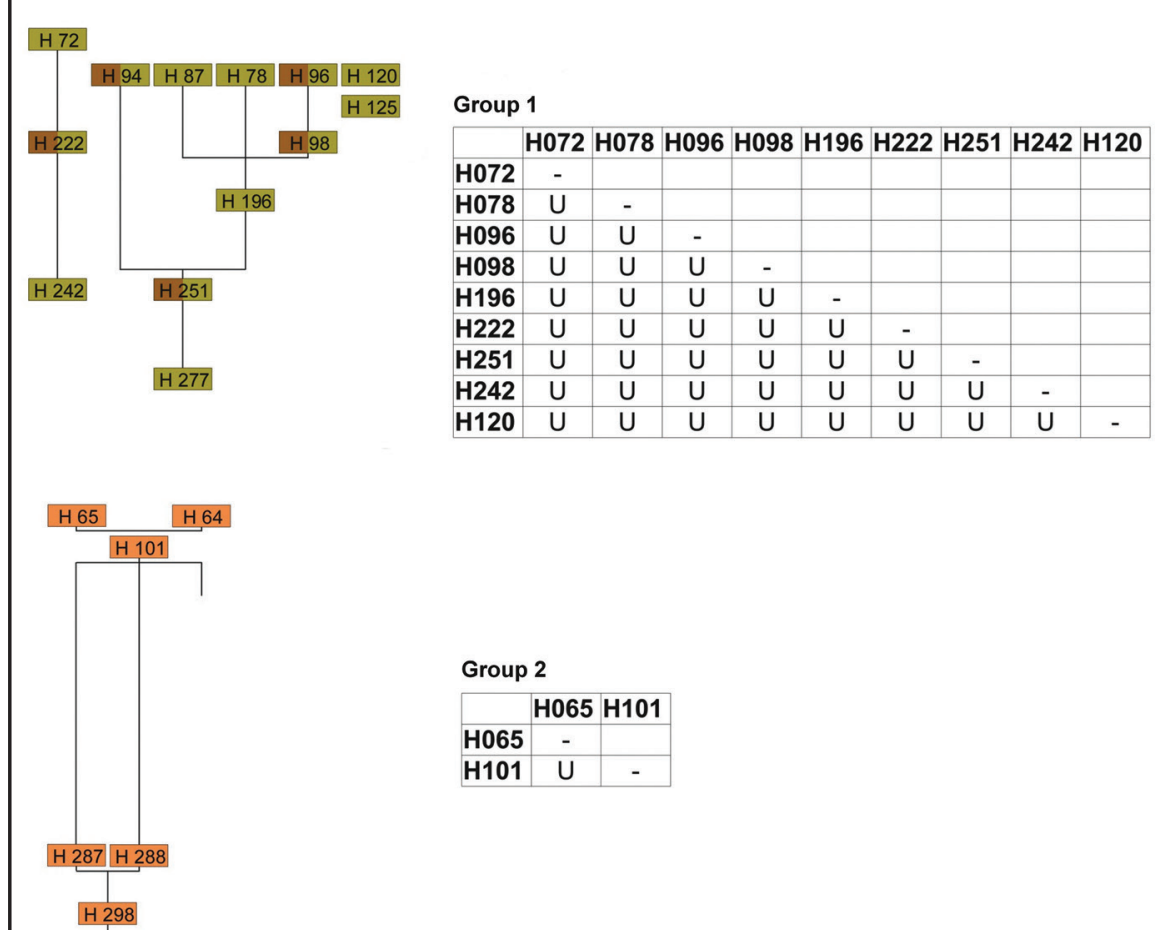

Group 2

\begin{tabular}{|c|c|c|}
\hline & H065 & H101 \\
\hline H065 & - & \\
\hline H101 & U & - \\
\hline
\end{tabular}

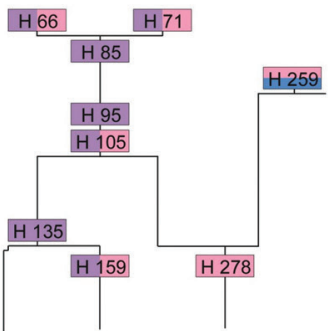

Group 3
\begin{tabular}{|l|c|c|c|c|c|}
\hline & H066a H066b & H066c & H071 & H085 \\
\hline H066a & - & & & & \\
\hline H066b & U & - & & & \\
\hline H066c & U & U & - & & \\
\hline H071 & U & U & U & - & \\
\hline H085 & U & U & U & U & - \\
\hline
\end{tabular}

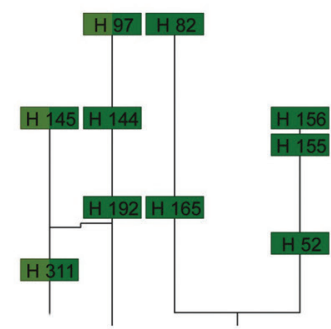

Group 4

\begin{tabular}{|l|c|c|c|c|c|}
\hline & H082 H097 & H165 & H145 H192 \\
\hline H082 & - & & & & \\
\hline H097 & U & - & & & \\
\hline H165 & U & U & - & & \\
\hline H145 & U & U & U & - & \\
\hline H192 & U & U & U & U & - \\
\hline
\end{tabular}

Figure 3. Skeletal remains of individuals H66 and H71 (in blue). Grave H66 contained skeletal remains of an adult female with additional bones (in green) of a child and adult male. Photographed by Jiří Vachuda.

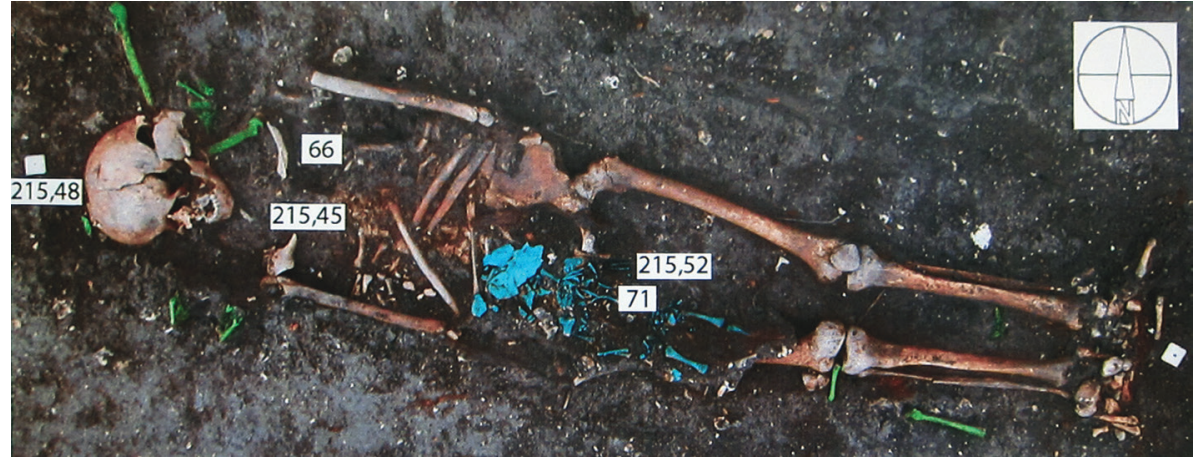


Table 1. The list of individuals analysed.

\begin{tabular}{|c|c|c|c|c|c|c|c|}
\hline No. & ID & $\begin{array}{l}\text { Sex determined } \\
\text { anthropologically }\end{array}$ & $\begin{array}{l}\text { Age determined } \\
\text { anthropologically }\end{array}$ & $\begin{array}{c}\text { Analysed part of } \\
\text { skeleton }\end{array}$ & $\begin{array}{c}\text { Concentration } \\
\text { of aDNA (pg/ul) }\end{array}$ & $\begin{array}{l}\text { Inventory } \\
\text { number }\end{array}$ & Group \\
\hline 1. & H72/I & \multirow{2}{*}{ female } & \multirow{2}{*}{$30-40$} & tooth & 33.4 & \multirow{2}{*}{ P7A 19001} & \multirow{2}{*}{1} \\
\hline 2. & H72/II & & & bone & 4.64 & & \\
\hline 3. & H78/I & \multirow{2}{*}{ undetermined } & \multirow{2}{*}{$2-3$} & tooth & 1.55 & \multirow{2}{*}{ P7A 19007} & \multirow{2}{*}{1} \\
\hline 4. & H78/II & & & bone & 36 & & \\
\hline 5. & H94/I & \multirow{2}{*}{ undetermined } & \multirow{2}{*}{ juvenis } & tooth & 4.22 & \multirow{2}{*}{ P7A 19021} & \multirow{2}{*}{1} \\
\hline 6. & H94/II & & & bone & 5.25 & & \\
\hline 7. & H96/I & \multirow{2}{*}{ female } & \multirow{2}{*}{$50-60$} & metatarsal & 0.24 & \multirow{2}{*}{ P7A 19023} & \multirow{2}{*}{1} \\
\hline 8. & H96/II & & & rib & 8.03 & & \\
\hline 9. & H98/I & female & $30-40$ & tooth & 2.46 & P7A 19025 & 1 \\
\hline 10. & H196/I & \multirow{2}{*}{ male } & \multirow{2}{*}{ maturus } & tooth & 15.3 & \multirow{2}{*}{ P7A 19122} & \multirow{2}{*}{1} \\
\hline 11. & H196/II & & & rib & 11.6 & & \\
\hline 12. & H222/I & \multirow{2}{*}{ male } & \multirow{2}{*}{$40-50$} & ulna & 394 & & \\
\hline 13. & H222/II & & & tooth & 366 & P7A 19162 & 1 \\
\hline 14. & H251/I & & & tooth & 2.11 & & \\
\hline 15. & H251/II & female & $30-40$ & tooth & 0.9 & P7A 19173 & 1 \\
\hline 16. & H120/I & & & ulna & 9.06 & & \\
\hline 17. & H120/II & undetermined & newborn & $\mathrm{rib}$ & 66 & P7A 19047 & 1 \\
\hline 18. & H242/I & & & bone & 4.32 & & \\
\hline 19. & H242/II & undetermined & juvenis & rib & 2.12 & P7A 19162 & 1 \\
\hline 20. & H64/I & & & tooth & 1.26 & & \\
\hline 21. & H64/II & undetermined & 18 months & bone & 2.54 & P7A 18993 & 2 \\
\hline 22. & H65/I & & & humerus & 35.7 & & \\
\hline 23. & H65/II & undetermined & newborn & rib & 68.1 & P7A 18994 & 2 \\
\hline 24. & H101/I & femole & & tooth & 47.4 & P7A 10028 & 2 \\
\hline 25. & H101/II & female & maturus & rib & 1.25 & P7A 19028 & 2 \\
\hline 26. & H66а/I & & & tooth & 6 & & \\
\hline 27. & H66а/II & female & maturus & tooth & 17.8 & & \\
\hline 28. & H66b/I & undeterminod & iunonic & rib & 11.4 & D7 18005 & 3 \\
\hline 29. & H66b/II & undetermined & juvenis & bone & 2.04 & P/A 18995 & 3 \\
\hline 30. & H66c/I & mole & maturus & tooth & 2.79 & & \\
\hline 31. & H66e/II & male & maturus & tooth & 31.3 & & \\
\hline 32. & H71/I & & & femur & 2.62 & & 3 \\
\hline 33. & H71/II & undetermined & newborn & os petrosum & 69.2 & P7A 19000 & 3 \\
\hline 34. & H85/I & & & tooth & 0.5 & & \\
\hline 35. & H85/II & female & $20-30$ & tooth & 5.95 & P7A 19014 & 3 \\
\hline 36. & H85/III & & & tooth & 2.16 & & \\
\hline 37. & H82/I & & & radium & 3.8 & & \\
\hline 38. & H82/II & undetermined & newborn & phalang & 2.93 & P7A 19011 & 4 \\
\hline 39. & H97/I & & & calf bone & 2.49 & & \\
\hline 40. & H97/II & female & $50-60$ & phalang & 1.29 & P7A 19024 & 4 \\
\hline 41. & H165/I & & & tooth & 35.2 & & \\
\hline 42. & H165/II & female & $40-50$ & os petrosum & 396 & P7A 19092 & 4 \\
\hline 43. & H145/I & & & os petrosum & 317 & & 4 \\
\hline 44. & H145/II & male & adultus & tooth & 17.5 & P7A 17072 & 4 \\
\hline 45. & H192/I & & & tooth & 24.9 & & \\
\hline 46. & H192/II & male & adultus & metacarpus & 1.97 & P7A 19118 & 4 \\
\hline
\end{tabular}


see Figure 3). Samples of teeth and bones were taken from different parts of the skeletons, depending on their state of skeletal preservation. For detailed information about the samplings, see Table 1. Sampling took place in the National Museum in Prague, where the remains are deposited.

Samples were analysed in several independent steps in four separate rooms (mechanical cleaning; extraction of aDNA; quantification and PCR amplification; post-PCR sequencing). Blank controls were added to each step/reaction to monitor for possible contamination resulting from the lab procedures, but revealed no evidence thereof.

\subsection{Mechanical cleaning and extraction of aDNA}

Samples were rinsed using 96\% ethanol and ultra clean water. Bone and teeth surfaces were sanded using either a Dremel Multi (Dremel) electric mini sander, or manually using sandpaper due to a sample's preservation. Bones were cut into small pieces and ground into powder using a 6870 Freezer Mill (Spex Sample Prep). Subsequently, 70mg of the bone powder was incubated in a lysis buffer $(0.5 \mathrm{M}$ EDTA [pH 8.0], Proteinase $\mathrm{K}$ and $0.5 \% \mathrm{SDS})$ at $56^{\circ} \mathrm{C}$ in a UVP HB-1000 Hybridizer Hybridization Oven (Analytik Jena US LLC) for 24 hours. Finally, aDNA was extracted using a MinElute PCR Purification Kit (Qiagen) according to a modified protocol published by Yang et al. (1998) and Anderung et al. (2008).

\subsection{Quantification of aDNA}

The success of the extraction of preserved aDNA and the amount of extracted aDNA was determined using a real-time PCR quantification Plexor HY System (Promega) kit on a LightCycler 480 RealTime PCR Instrument (Roche). Samples were prepared in duplex reactions. The Plexor HY kit contains primer for a target of a 133bp sequence from a testis-specific protein, Y-encoded (TSPY) locus on chromosome Y, providing means of determining genetic sex.

\subsection{Amplification and sequencing of aDNA}

Samples were analysed for 23 autosomal STR markers, amelogenin X and Y, and 23 Y-chromosomal STR markers using four commercially-available kits: the PowerPlex ESX 17 System, the PowerPlex ESI 17 Pro System, the PowerPlex 16 System, and the PowerPlex Y23 System (all from Promega Corporation). Amelogenin $\mathrm{X}$ and $\mathrm{Y}$ loci were used to determine genetic sex. Each sample was analysed in several independent amplifications and sequencing reactions using peqSTAR 96X Universal Gradient cycler (VWR Peqlab) and the Applied Biosystems 3130xl Genetic Analyzers instrument $(15 \mathrm{kV}$ injection for $15 \mathrm{~s}$ at POP4 polymer) (Applied Biosystems). Samples were prepared according to the manufacturer's recommendation with 32 amplification cycles instead of the 30 that were recommended by the manufacture protocol.

\subsection{Data analyses}

Raw data from capillary electrophoresis were analysed with GeneMapper IDX software (Applied Biosystems). Results of autosomal and Y-chromosomal STR markers were used for genetic kinship and genetic sex determination among buried individuals. Results of STR markers were evaluated and computed by several software programs: Mlrelate (Kalinowski et al., 2006), Familias 3 (Kling et al., 2014), Network 5 (Bandelt et al., 1999), and Network Publisher 2.1.2.5 (Fluxus Technology LtD.) A phylogenetic network of Y-chromosomal STR markers was constructed only for markers that were successfully genotyped in all male samples. The network was constructed using Median joining (Bandelt et al., 1999), and the final tree was redrawn by Network Publisher 2.1.2.5 (Fluxus Technology LtD). Genetic kinship between samples in all groups was computed by one to one for all samples using software Familias 3, that differentiated between five categories of genetic relationship (parent-offspring, full siblings, half siblings, cousins and second cousins) as well as unrelated individuals using Blind search by calculating a likelihood ratio (Kling et al., 2014) and ML-Relate (Kalinowski et al., 2006) that determined three close relationships (parent-offspring, full siblings and half siblings) and unrelated individuals (Kalinowski et al., 2006).

\section{Results}

The success of the genetic analyses depends on the quantity and quality of the extracted aDNA (Table 1). Genetic sex and genetic kinship was evaluated for individuals that were successfully genotyped in several independent reactions of two or three different samples from one individual. Samples H64 and H94 were excluded from the statistical analyses, since sample H64 failed to be successfully genotyped, and sample H94 did not provide reliable results (results from two different parts of the skeleton gave different results). The skeletal remains of H94 were excavated during two different archaeological excavations and it is possible that the two parts of the skeleton were completed incorrectly.

\subsection{Genetic kinship}

Genetic kinship was determined from the result of autosomal (Table 2) and Y chromosomal STR markers (Table 3). STR profiles listed in Table 2 and Table 3 are summaries of all performed analyses from all kits, as well as all samples analysed for the same individual. The success rate of STR marker detection was increased using three different available autosomal kits. Ancient DNA is degraded into small fragments over time, and it is necessary to analyse small fragments (Allentoft et al., 2012; Pääbo, 1989). The advantage of using the PowerPlex ESX 17 System and PowerPlex ESI 17 Pro System kits as complements is that while they contain the same markers, the primers are designed to complement one another, with a different final marker length. Markers that are long in the first kit are short in the second. The stratigraphic relation between individuals within the burial grounds is shown on flowcharts below (Figure 2). Genetic analyses revealed only unrelated 

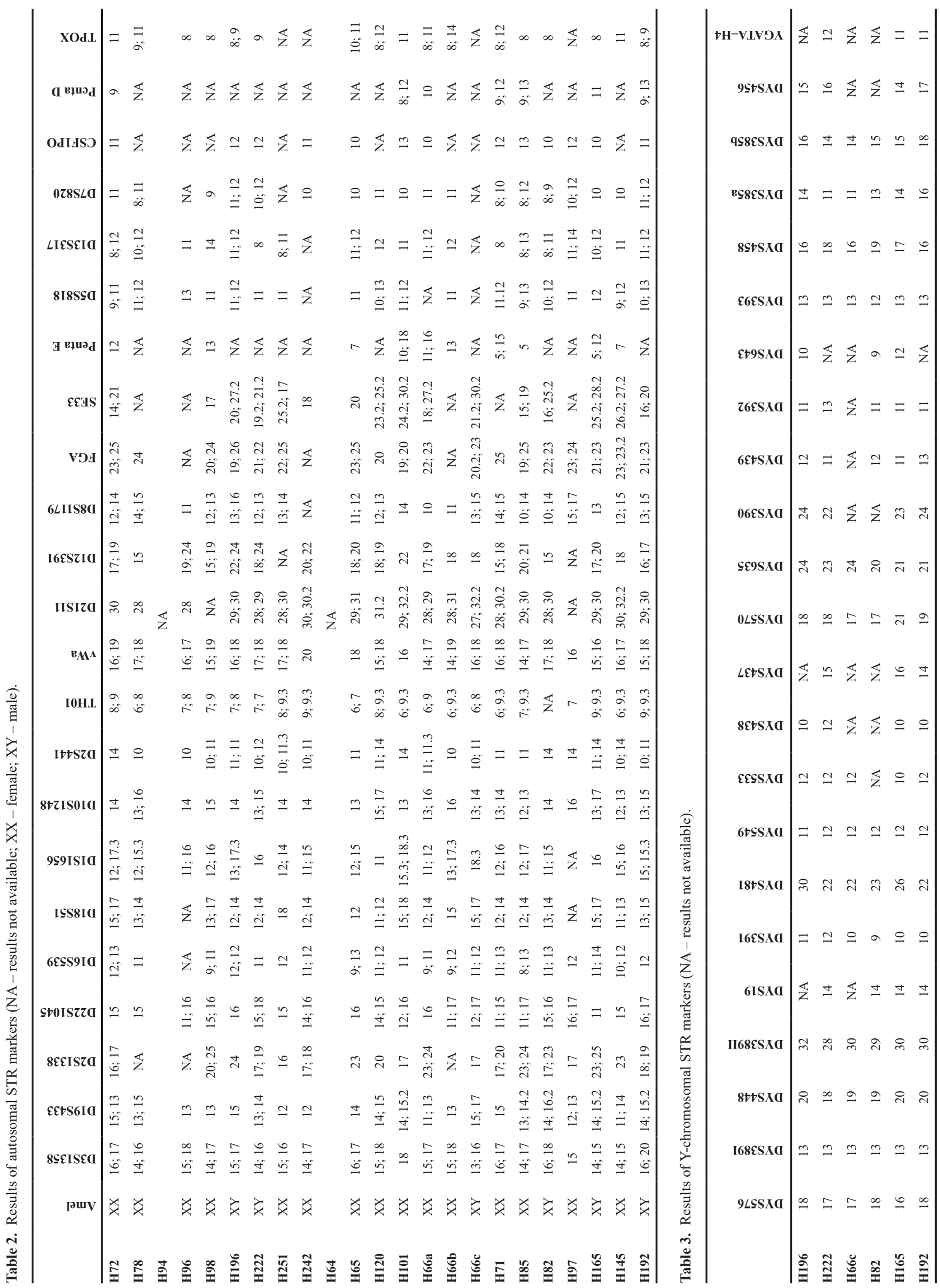
relationships between analysed samples within all groups. The matrix generated by Ml-Relate software (Figure 2), provides information that individuals in all groups are not blood-related.

Six individuals were determined by a signal for amelogenin $\mathrm{Y}$ as a male and were analysed for Y-chromosomal STR markers (Table 3). All identified male individuals differed considerably from each other in terms of observed alleles (Figure 4), providing no evidence of any father-son relationships, nor of a common close male ancestor.

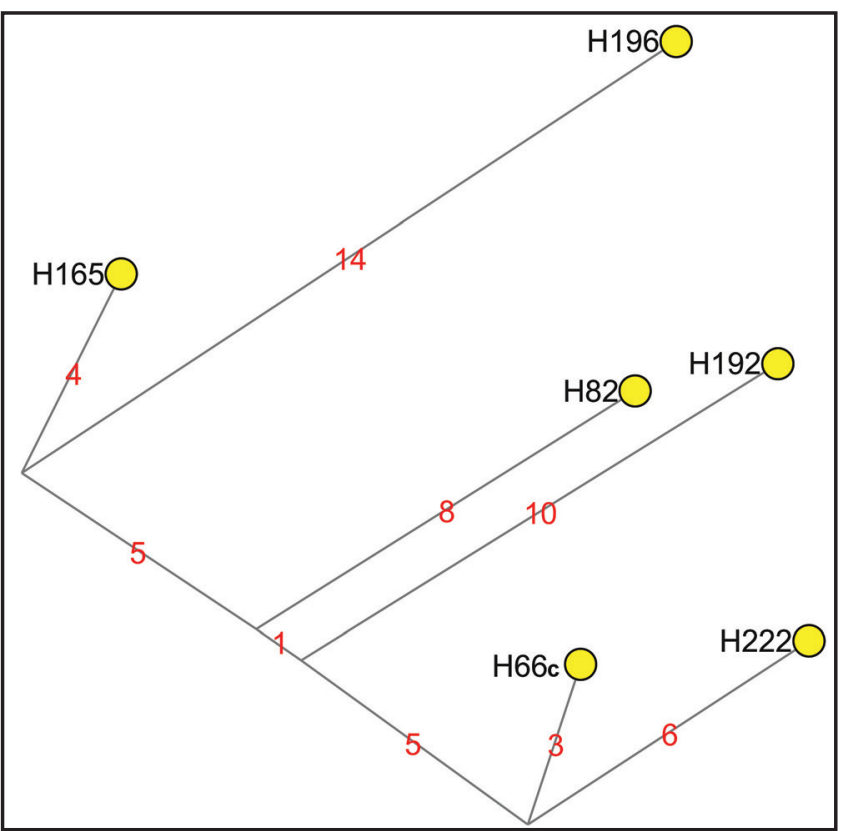

Figure 4. The phylogenetic network constructed for Y-chromosomal STR markers (yellow rings-individuals; red numbers-number of mutations).

\subsection{Sex determination}

The presence/absence of a signal for amelogenin Y locus was used to determine the genetic sex of skeletal remains (XX - female and XY - male). Six individuals determined as a male by the presence of a signal for amelogenin $\mathrm{Y}$ were successfully genotyped for Y-chromosomal STR markers. Due to the fact that the amelogenin Y locus can be affected by allelic drop-out, we also took the result of the amplification TSPY gene in the Plexor HY kit into consideration. All samples that did not have a signal for amelogenin $\mathrm{Y}$ were also not amplified for the Y-chromosomal TSPY gene, and genetic sex was classified as a female (Table 4). Our results were compared with the morphological findings of studies performed by Milan Stloukal from the Department of Archaeology of the National Museum in Prague. His unpublished morphological examinations of skeletal remains are archived in the Department of Archaeology in the National Heritage Institute in Prague. The anthropological sex and age of the skeletal remains were determined using methods in accordance to the protocol by Ferembach et al. (1979). We observed two cases of discordance (for individuals H145 and H165) between morphological and genetic findings (see Table 4), and thus were able to increase the rate of sex determination from $61 \%$ for morphological findings (14 individuals) to $91 \%$ (21 individuals) for genetic findings. We were also able to determine the sex of children that could not be evaluated by morphological methods. Both individuals H145 and H165 were poorly preserved, having seriously damaged skeletons and fragmented skulls.

\section{Discussion}

The results of the genetic analyses confirmed the hypothesis about the funerary practices of Early Modern period burghers, which was based on the study of historical written sources such as death registers, parish registers and testaments. Historical written sources did not provide any clear information about the existence of family graves on the bourgeois graveyard of St. John the Baptist church in the in Early Modern period village of Obora. Genetic analyses revealed that the individuals, who were buried in the same

Table 4. Results of morphological and genetic sex determination; discordances between morphological and genetic findings are labelled in red.

\begin{tabular}{cccccccc}
\hline No. & ID & $\begin{array}{c}\text { Sex determined } \\
\text { antropologically }\end{array}$ & $\begin{array}{c}\text { Sex determined } \\
\text { genetically }\end{array}$ & No. & ID & $\begin{array}{c}\text { Sex determined } \\
\text { antropologically }\end{array}$ & $\begin{array}{c}\text { Sex determined } \\
\text { genetically }\end{array}$ \\
\hline 1. & $\mathbf{H 7 2}$ & female & female & 13. & $\mathbf{H 1 0 1}$ & female & female \\
2. & $\mathbf{H 7 8}$ & undetermined & female & 14. & $\mathbf{H 6 6 a}$ & female & female \\
3. & $\mathbf{H 9 4}$ & undetermined & undetermined & 15. & $\mathbf{H 6 6 b}$ & undetermined & female \\
4. & $\mathbf{H 9 6}$ & female & female & 16. & $\mathbf{H 6 6 c}$ & male & male \\
5. & $\mathbf{H 9 8}$ & female & female & 17. & $\mathbf{H 7 1}$ & undetermined & female \\
6. & $\mathbf{H 1 9 6}$ & male & male & 18. & $\mathbf{H 8 5}$ & female & female \\
7. & $\mathbf{H 2 2 2}$ & male & male & 19. & $\mathbf{H 8 2}$ & undetermined & male \\
8. & $\mathbf{H 2 5 1}$ & female & female & 20. & $\mathbf{H 9 7}$ & female & female \\
9. & $\mathbf{H 1 2 0}$ & undetermined & female & 21. & $\mathbf{H 1 6 5}$ & female & male \\
10. & $\mathbf{H 2 4 2}$ & undetermined & female & 22. & $\mathbf{H 1 4 5}$ & male & female \\
11. & $\mathbf{H 6 4}$ & undetermined & undetermined & 23. & $\mathbf{H 1 9 2}$ & male & male \\
12. & $\mathbf{H 6 5}$ & undetermined & female & & & & \\
\hline
\end{tabular}


multi-level graves or in neighbouring graves, are not bloodrelated members of a single family.

The evidence from parish and civil registers suggests that bourgeois (middle class) members of society were buried in accordance to the parish affiliation of the given house which was the site of their death. Division of a family at the time of death was not unusual in that period. As a case in point, we can mention the burials of the young boy Johann Roßlaw and his mother. Although the boy died on $3^{\text {rd }}$ May 1764 and his mother on $22^{\text {nd }}$ May 1764, they were not buried in the same grave, nor even at the same graveyard as a result of the different parish affiliation of the houses in which their death took place. The boy died at the "House of Three Swallows" and was buried at the graveyard of the Church of St. John the Baptist, but his mother died at "Schumann House", and was buried at the graveyard of the Church of St. Lawrence. Her daughter Rosina died in October 1764 at the house " $U$ Jedličkư" and was buried at the graveyard of the Church of the St. Lawrence (Prague City Archives, Collection of Matrices, sign. MIK Z4, fold 19-20 and 22; Omelka, Řebounová, 2012a, p.239). A very similar example was in the case of the Roßenfeld family. Three of the five children were buried at the graveyard of the Church of St. Lawrence and two at the graveyard of the Church of St. John the Baptist. It was also probably due to their different parish affiliations (Prague City Archives, Collection of Matrices, sign MIK Z3, fold 310 and 313; sign MIK Z4, fold 20 and 31).

Other useful sources of funerary practices can be gleaned from testaments. Testaments of aristocratic and the richest, social-bourgeoisie class individuals, who were usually buried in church interiors, were written very precisely, containing detailed information about where exactly they want to be buried and even with whom they wish to be buried after death (Král, 2005; Nováčková et al., 2019, in press). The graveyard of the Church of St. John the Baptist was mainly used to bury citizens belonging to the middle or lower-middle social classes, and individual testaments (if written) usually only specified the name of the church. We can mention, for example, the testament of František Dispach. He died in 1766 in his house in Lesser Town, which belongs to the parish district of the Church of St. John the Baptist. His testament was written only several months before his death, and he wanted to be buried at the graveyard of the Church of St. John the Baptist or the graveyard of the Church of St. Wenceslas. Finally, he was buried at the graveyard of the Church of St. Wenceslas (Manuscript Collection, sign 4764, fol. A21-A22) and not at the graveyard of the Church of St. John the Baptist, where his five children had been buried before him (Anna died in 1731, Vaclav in 1737, Theresie in 1743, Ludmila in 1743, and Antonie in 1750). All his children died in their father's house (Prague City Archives, Collection of Registries, sign MIK 3, fol. 185, 211, 253, 256 and 281). There is also mention of Anna Dispachova, who died in 1742 in the house "At the White Angel", and was buried at the graveyard of the Church of St John the Baptist, but the relationship with František Dispacha is not clear from the register (Archive of the City of Prague,
Collection of Registries, sign MIK 3, fol. 236). It is evident that family relationships were not taken into consideration when members of one family were buried.

According to the data from historical written sources and from the results of genetic analyses, there is no indication that people from the Early Modern period's lower and middle social classes (i.e. most of the people buried at graveyard of the Church of the St. John the Baptist) of purposefullyburied members of one family were buried in one multilevel grave, or in neighbourhood grave sites, or even in the same graveyard, as was the very common practice of the aristocracy and the richest among the population (Král, 2005).

\section{Conclusion}

In this study we have applied an interdisciplinary approach to investigate genetic kinship, genetic sex and the funerary practices of an Early Modern period bourgeois society. Genetic analyses are a powerful method for sex determination in skeletons of children, as well as in badly-preserved and incomplete skeletons of adults (Álvarez-Sandova et al., 2014; Lassen et al.,2000; Tierney, Bird, 2014), where morphological methods provide unreliable or no results (Álvarez-Sandova et al., 2014; Lassen et al., 2000; Tierney, Bird, 2014). We observed a contradiction between morphological and genetic methods in the sex determination of two separate skeletons of buried individuals: individuals H145 and H165 were poorly preserved, resulting in an unreliable morphological determination of sex. In such cases, genetic analyses are a more exact method to determine the sex of skeletal remains than are morphological treatments. By implementing genetic analyses, the number of successfully-determined individuals increased from $14(61 \%)$ to $21(91 \%)$; in addition, we were able to determine the genetic sex of children that could not be determined through morphological methods.

Genetic analyses are a crucial tool in determining the genetic kinship of archaeological skeletal remains. The skeletal samples used for genetic analyses were chosen according to their relative stratigraphic positions within the burial grounds, and divided into four groups. Skeletons of adults and children buried in the same multi-level grave, or in very close proximity, have a high probability of being members of the same family. Genetic analyses of autosomal and Y-chromosomal STR markers revealed, however, that the individuals analysed were not blood-relatives. These results of genetic analyses are in accordance with and confirm the hypothesis based on the evidence provided by written historical sources (civil and parish registers and testaments). There is evidence that some members of families of middle and lower social classes were buried in different graveyards: because they had died in different houses belonging to a different parish affiliation. The tradition of founding family graves at that time is well documented among aristocratic families and the more wealthy inhabitants, who were usually buried together; however, this would be in the interior of the 
church. On the other hand, the majority of baroque inhabitants of the past village of Obora buried at the graveyard of the Church of St. John the Baptist were probably buried there wherever a free place was available and according to their parish affiliation, without taking blood relationships into consideration.

\section{Acknowledgements}

The research of family relationships of skeletal remains was supported by a grant from the Ministry of the Interior of the Czech Republic (VI20162020015). We are grateful to the National Museum in Prague for allowing us to sample the human remains in their possession.

\section{References}

ALLENTOFT, M.E., COLLINS, M., HARKER, D., HAILE, J., OSKAM, C.L., HALE, M.L., CAMPOS, P F., SAMANIEGO, J.A., GILBERT, M.T., WILLERSLEV, E, ZHANG, G., SCOFIELD, R P., HOLDAWAY, R.N., BUNCE, M., 2012. The half-life of DNA in bone: measuring decay kinetics in 158 dated fossils. Proceedings Biological Sciences, 279(1748), 4724-4733

ÁLVAREZ-SANDOVAL, B.A., MANZANILLA, L.R., MONTIEL, R., 2014. Sex Determination in Highly Fragmented Human DNA by HighResolution Melting (HRM) Analysis. PLoS ONE, 9(8), e104629.

ANDERUNG, C., PERSSON, P., BOUWMAN, A., ELBURG, R., GÖTHERSTRÖM, A., 2008. Fishing for ancient DNA. Forensic Science International: Genetics, 2(2), 104-107.

BANDELT, H.J., FORSTER, P., RÖHL, A., 1999. Median-joining networks for inferring intraspecific phylogenies. Molecular Biology and Evolution, 16(1), 37-48

BOBEROVÁ, K., DROZDOVÁ, E., PÍŽOVÁ, K., 2012. Application of Molecular Genetic Methods in Anthropological and Paleodemographic Studies of Fragmentary and Damaged Skeletal Material from Rescue Excavations. Journal of Life Sciences, 6(9), 961-969.

BRAVERMANOVÁ, M., DOBISÍKOVÁ, M., FROLÍK, J., KAUPOVÁ, S., STRÁNSKÁ, P., SVĚTLÍK, I., VANĚK, D., VELEMÍNSKÝ, P., VOTRUBOVÁ, J. 2018. Nové poznatky o ostatcích z hrobů K1 a K2 rotundy sv. Víta na Pražském hradě - New findings on the remains from graves K1 and K2 from the St. Vitus Rotunda at Prague Castle Archeologické rozhledy, 70, 260-293.

CUI, Y., SONG, L., WEI, D., PANG, Y., WANG, N., LI, C., FENG, B., TANG, W., LI, H., REN, Y., ZHANG, C., HUANG, Y., HU, Y., ZHOU, H., 2015. Identification of kinship and occupant status in Mongolian noble burials of the Yuan Dynasty through a multidisciplinary approach. Philosophical Transactions of the Royal Society B: Biological Sciences, 370(1660), 20130378.

DAMGAARD, P.B., MARGARYAN, A., SCHROEDER, H., ORLANDO, L., WILLERSLEV, E., ALLENTOFT, M.E., 2015. Improving access to endogenous DNA in ancient bones and teeth. Scientific Reports, 5, 11184.

DEGUILlouX, M., PEMONGE, M., MENDISCO, F., THIBON, D., CARTRON, I., CASTEX, D., 2014. Ancient DNA and kinship analysis of human remains deposited in Merovingian necropolis sarcophagi (Jau Dignac et Loirac, France, $7^{\text {th }}-8^{\text {th }}$ century AD). Journal of Archaeological Science, 41, 399-405.

DRAGOUN, Z., 1988a. Archeologický výzkum rotundy sv. Jana Křtitele pod Pražským hradem v r. 1986 a 1987 - Archaeological Excavation of the Rotunda of St. John the Baptist below Prague Castle in 1986-1987 (in Czech). Archaeologia historica, 13, 403-416.

DRAGOUN, Z., 1988b. Praha 1 - Malá Strana, Jánský vršek, Šporkova ulice - Prague 1 - Lesser Town, Jánský vršek, Šporkova street (in Czech). Pražský sbornik historický, 21, 184-185.

DRAGOUN, Z. 1991. Praha 1 - Malá Strana, Jánský vršek - Prague 1 -
Lesser Town, Jánský vršek, Šporkova street (in Czech). Pražský sbornik historický, 24, 195-196.

FEREMBACH, D., SCHWIDETZKY, I., STLOUKAL, M., 1979. Empfehlungen fur die Alters- und Geschlechtsdiagnose am Skelett. Homo, 30, 1-32.

FROLÍK, J., STRÁNSKÁ, P., VOTRUBOVÁ, J., EMMEROVÁ, B., VANĚK, D., 2017. People "on the Margin": A Medieval Cemetery in Český Brod - Malechov (Central Bohemia). Interdisciplinaria Archaelogica: Natural Sciences in Archaeology, 8(1), 59-75.

GAMBA, C., JONES, E.P., TEASDALE, M.D., McLAUGHLIN, R.L., GONZALES-FORTES, G., MATTIANGELI, V., DOMBRÓCZKI, L., KÖVÁRI, I., PAP, I., ANDERS, A., WHITTLE, A., DANI, J., RACZKY, P., HIGHAM, T.F.G., HOFREITER, M., BRADLEY, D.G., PINHASI, R., 2014. Genome flux and stasis in a five millennium transect of European prehistory. Nature Communications, 5(5257), 5257.

HANSEN, H.B., DAMGAARD, P.B., MARGARYAN, A., STENDERUP, J., LYNNERUP, N., WILLERSLEV, E., ALLENTOFT, M.E., 2017. Comparing Ancient DNA Preservation in Petrous Bone and Tooth Cementum. PLoS ONE. 12(1), e0170940.

HOFREITER, M., SERRE, D., POINAR, H.N., KUCH, M., PÄÄBO, S., 2001. Ancient DNA. Nature Reviews Genetics, 2(5), 353-359.

JURAS, A., CHYLENSKI, M., KRENZ-NIEDBALA, M., MALMSTROM, H., EHLER, E., POSPIESZNY, L., LUKASIK, S., BEDNARCZYK, J., PIONTEK, J., JAKOBSSON, M., DABERT, M., 2017. Investigating kinship on Neolithic post-LBK human remains from Krusza Zamkova, Poland using ancient DNA. Forensic Science International: Genetics, 26, 30-39.

KALINOWSKI, S.T., WAGNER, A.P., TAPER, M.L., 2006. ML-Relate: a computer program for maximum likelihood estimation of relatedness and relationship. Molecular Ecology Notes, 6(2), 576-579.

KEYSER-TRACQUI, C., LUDES, B., 2005. Methods for the study of ancient DNA. Methods in molecular biology, 297, 253-264.

KLING, D., TILLMAR, A.O., EGELAND T., 2014. Familias 3-Extensions and new functionality. Forensic Science International: Genetics, 13, 121-127.

KRÁL, P. 2005: Tod, Begräbnisse und Gräber. Funeral ritus des böhmischen Adels als Mittel der Representation und des Andenkens. In: M. Hengere, ed. Macht und Memoria. Begräbniskultur europäischer Oberschichten in der Frühen Neuzeit. Köln, Weimar, Wien: Böhlau, pp. 421-448.

LASSEN, C., HUMMEL, S., HERRMANN, B., 2000. Molecular sex identification of stillborn and neonate individuals ("Traufkinder") from the burial site Aegerten. Anthropologischer Anzeiger, 58(1), 1-8.

MELCHIOR, L., LYNNERUP, N., SIEGISMUND, H.R., KIVISILD, T., DISSING, J., 2010. Genetic Diversity among Ancient Nordic Populations. PLoS One, 5(7), e11898.

NOVÁČKOVÁ, J., OMELKA, M., ŘEBOUNOVÁ, O., STENZL, V., in press. Begräbnispraxis des Pragerbarocken Bürgertums im Licht der DNA-Analyse. In: Internationale Tagung der Österreichischen Gesellschaft für Mittelalterarchäologie 2018. Sankt Pölten. Wien: Beiträge zur Mittelalterarchäologie in Österreich.

OMELKA, M., 2006a. Nález neobvykle členěného medailonu s vyobrazením kř́že svatého Benedikta a Zachariášova požehnaní ze Šporkovy ulice čp. 332/III v Praze - The Finds of Unusually Divided Medallion with a Motif of St. Benedict's cross and Zachary's Blessing from Šporkova Street, House No. 322/III in Prague (in Czech). Archeologica Pragensia, 18, 144-152.

OMELKA, M., 2006b. Investorská zpráva o archeologickém výzkumu Praha 1 - Malá Strana, Šporkova ulice čp. 332/III - Investor's report about archaeological research in Prague 1-The Lesser Town, Šporkova Street no. 322/III. Unpublished manuscript deposited in the Archive of the National Heritage Institute, ú. o. p. in Prague, Archive of the Department of Archaeology.

OMELKA, M., 2009. Hřbitov u kostela sv. Jana v Oboře ve Šporkově ulici čp. 332/III na Malé Straně v Praze - The Cemetery of the Church of St. John in Šporkova Street (no.322/III), the Lesser Town, Prague (in Czech). Staletá Praha, 25, 93-101.

OMELKA, M., PETř́́K, J., PROKEŠ, L., ŘEBOUNOVÁ, O., ŠLANCAROVÁ, V., 2018. Soubor knoflíků ze zaniklého hřbitova př́i kostelu sv. Jana v Oboře (Praha - Malá Strana) - An Assemblage of Buttons from the Defunct Cemetery at the church of Saint John the Baptist in Obora (Prague Lesser Town) (in Czech). Archeologie ve střednich Čechách, 22, 709-744. 
OMELKA, M., ŠLANCAROVÁ, V., 2007. Soubor prstenů ze zaniklého hřbitova při kostelu sv. Jana v Oboře (Praha - Malá Strana) - A Collection of Rings from the Defunct Cemetery at the church of Saint John the Baptist in Obora, Prague - the Lesser Town (in Czech). Archeologie ve středních Čechách, 11, 671-709.

OMELKA, M., Һ̌EBOUNOVÁ, O., 2008. Soubor korálků ze zaniklého hřbitova při kostelu sv. Jana v Oboře (Praha1 - Malá Strana) - A Collection of Beads from the Defunct Cemetery at the Church of St. John the Baptist in Obora, Prague-the Lesser Town (in Czech). Archeologie ve středních ऍ̌echách, 12, 606-679.

OMELKA, M., ŘEBOUNOVÁ, O., 2011. Poznámky ke zbožnosti a pohřebnímu ritu malostranského barokního měšt’anstva ve světle archeologických nálezů - Remarks on the Religiousness and Burial Rite of the Lesser Town Baroque Burghers in the Light of Archaeological Findings (in Czech). Pražský sborník historický, 39, 268-298.

OMELKA, M., ŘEBOUNOVÁ, O., 2012a. Soubor medailonů a feniků se symbolikou sv. Benedikta ze zaniklého hřbitova při kostelu sv. Jana v Oboře (Praha1 - Malá Strana) - A Collection of Medallions and Pfennigs with the Symbols of St. Benedict from the Defunct Cemetery at the Church of St. John in Obora (Prague-Lesser Town) (in Czech). Archeologie ve středních Čechách, 16/2, 983-1019.

OMELKA, M., ŘEBOUNOVÁ, O., 2012b. A view of the archaeological context of the Lesser Town cemetery in Šporkova Street in Prague using Modern period iconography and written sources. Studies in PostMedieval Archaeology, 4, 233-250.

OMELKA, M., ŘEBOUNOVÁ, O., 2014. Barokní mariánské kulty na Malé Straně v zrcadle pražských archeologických nálezů náboženských medailí (s přihlédnutím k situaci v Čechách a na Moravě) - Baroque Maria's Cults in the Lesser Town in the Mirror of Prague Archaeological Finds of Religious Medals (with Consideration to the Situation in Bohemia and Moravia). Pražský sborník historický, 42, 243-268.

OMELKA, M., ŘEBOUNOVÁ, O., 2016. Zboží pro chudé a bohaté „originály“ a dobové „padělky“ náboženských medailek na příkladu nálezů z hrobových kontextů - Products for the Poor and for the Rich: "Originals" and "Fakes" of Religious Medals on the Example of Finds from Grave Contexts (in Czech). Archaeologia historica, 41, 309-325.

OMELKA, M., ŘEBOUNOVÁ, O., 2017. Stav a perspektivy bádán novověkého pohřebního ritu v Čechách - The State and Perspectives of Research into Modern-Age Funeral Rites in Bohemia (in Czech). Archaeologia historica, 42, 117-133.

OMELKA, M., ŘEBOUNOVÁ, O., ŠLANCAROVÁ, V., 2009. Soubor kř́žků ze zaniklého hřbitova při kostelu sv. Jana v Oboře (Praha1 Malá Strana). I. Obecné formy křiže - A Collection of Crosses from the Defunct Cemetery at the Curch of St. John in Obora, Prague-Lesser Town. I. General Forms of Crosses (in Czech). Archeologie ve střednich Čechách, 13(2), 1001-1083.
OMELKA, M., ̌̌EBOUNOVÁ, O., ŠLANCAROVÁ, V., 2010. Soubor křížků ze zaniklého hřbitova při kostelu sv. Jana v Oboře (Praha1 - Malá Strana). II. Speciální kříže - A Collection of Crosses from the Defunct Cemetery at the Curch of St. John in Obora, Prague-Lesser Town. II. Special Crosses (in Czech). Archeologie ve středních Čechách, 14(1), 423-476.

OMELKA, M., ŘEBOUNOVÁ, O., ŠLANCAROVÁ, V., 2011. Špendlík - před hradbou a za hradbou - The Pin within and without the Town (in Czech). Archaeologia historica, 36, 23-540.

PÄÄBO, S., 1989. Ancient DNA: Extraction, characterization, molecular clonig, and enzymatic amplification. Proceedings of the National Academy of Sciences of the United States of America, 86(6), 1939-1943.

PÄÄBO, S., POINAR, H., JAENICKE-DESPRES, V., HEBLER, J., ROHLAND, N., KUCH, M., KRAUSE, J., VIGILANT, L., HOFREITER, M., 2004. Genetic analyses from ancient DNA. Annual Reviews of Genetics, 38, 645-679.

PINHASI, R., FERNANDES, D., SIRAK, M., CONNELL, S., ALPASLANROODENBERG, S., GERRITSEN, F., MOISEYEV, V., GROMOV, A., RACZKY, P., ANDERS, A., PIETRUSEWSKY, M., ROLLEFSON, G., JOVANOVIC, M., TRINHHOANG, H., BAR-OZ, G., OXENHAM, M., MATSUMURA, H., HOFREITER, M., 2015. Optimal Ancient DNA Yields from the Inner Ear Part of the Human Petrous Bone. PLOS One, 10(6), e0129102.

SIMÓN, M., JORDANA, X., ARMENTANO, N., SANTOS, C., DÍAZ, N., SOLÓRZANO, E., LÓPEZ, J.B. GONZÁLEZ-RUIZ, M., MALGOSA, A., 2011. The presence of nuclear families in prehistoric collective burials revisited: The bronze age burial of montanissell cave (spain) in the light of aDNA. American Journal of Physical Anthropology, 146(3), 406-413.

TIERNEY, S., BIRD, J., 2014. Sex identification of human remains from an Irish Medieval population using biomolecular methods. European Scientific Journal, 2, 521-530.

YANG, D.Y., ENG, B., WAYE, J.S., DUDAR, J.C., SAUNDERS, S.R., 1998. Improved DNA extraction from ancient bones using silica-based spin columns. American Journal of Physical Anthropology, 105(4), 539543.

YANG, D.Y. WATT, K., 2005. Contamination controls when preparing archaeological remains for ancient DNA analysis. Journal of Archaeological Science, 32(3), 331-336.

\section{Other Sources}

Prague City Archives, Collection of Registries, sign MIK Z3, MIK Z4, MIK Z5.

Prague City Archives, Manuscript Collection, sign 4764.

The National Heritage Institute in Prague, Archive of the Department of Archaeology, Documentation of excavations no. 30/02 and 30/04. 